\title{
Tax incentives for modernization of the Russian economy
}

\author{
Igor Lukasevich ${ }^{*}$, Panskov Vladimir, Sukhorukova Daria \\ Financial University under the Government of the Russian Federation, Russian Federation \\ *Corresponding author: Igor Lukasevich, Doctor of Science, lukas1963@yandex.ru
}

\begin{abstract}
The economic crisis has aggravated the socio-economic situation in Russia. In this condition the stable economic growth can be provided only through the increase of investments in the creation of new productive capacity. An important approach to solving this problem is the system of tax mechanisms that can ensure the effective stimulation effect on the expansion of investment and innovation activity. The tax mechanisms proposed in this paper will increase the investment activity and increase the pace of economic development in Russia.
\end{abstract}

Key words: tax reform, tax policy, modernization, investment, depreciation policy, tax credit

\section{Introduction}

The economic crisis, which is connected with the influence of both external (the decrease of world energy prices, economic sanctions) and internal (the weakening of the ruble exchange rate, interconnection between budget revenue and world prices) factors, has aggravated the socio-economic situation in Russia. Over the last years there has been evidence of negative GDP growth, the investment activity has been declining, and the inflation has been decreasing. ${ }^{1}$

In new conditions, the stable economic growth can be provided only through the increase of investments in the creation of new productive capacity and in the development of cut-edge technologies that increase labour productivity. At present, it is necessary to improve the investment climate in the country, but also to find the necessary financial resources.

\section{Results and discussions}

\subsection{The development of the tax mechanisms}

An important approach to solving this problem is the system of tax mechanisms that can ensure the effective stimulation effect on the expansion of investment and innovation activity. In our opinion suggested measures in the field of stimulation and regulation of economic development should be carried out in three directions: to revise the list, procedure and conditions for granting tax incentives for business, to conduct depreciation reform in the country, as well as change the terms of the investment tax credit (eg. V.G. Panskov et al. ${ }^{3}$ ).

The analysis shows that a great number of tax preferences operating in the Russian tax system are impersonal, since the targets for their provision are not set, and the directions of the use of released financial resources are not provided. According to Rosstat in 2015 Russian organizations have invested in fixed assets 14.6 trillion rubles. ${ }^{4}$ At the same time, their investments in financial assets were higher by 8.6 times and amounted to 127.1 trillion rubles. It is important to emphasize that this correlation between investments in fixed assets and investments in financial assets that are not connected with them is typical for all the past years of the country's tax reform. Furthermore, this ratio increases even more in favor of 
investments in financial assets in times of crisis.

Another problem is the inefficient structure of direct investments in fixed assets, which prevents the modernization and renewal of production.

For example, in 2015 the Russian companies invested 5 trillion rubles for the purchase of machinery, equipment and vehicles, which equals only $34.7 \%$ of total investments. ${ }^{2}$

Another factor that does not contribute to the translation of the Russian economy back on modernization and renovation track is the branch structure of investments in fixed assets. The renewal of fixed assets of manufacturing got 2.3 trillion rubles in 2015 or $15.7 \%$ of total direct investment in fixed capital, which is lower than the amount of funds allocated for the renovation of the production of companies, which accounted for 18,0\% (2,7 trillion rubles). ${ }^{5}$ These figures make Russian business investments in other assets look quite bleak. For example, investments in debt securities and deposit certificates accounted for 10.0 trillion rubles during the 1st half of 2016 alone, and bank deposits amounted to 25.9 trillion rubles. ${ }^{6}$

According to the reported data, currently not more than $17-18 \%$ of the total amount of profit remaining at the disposal of organizations after tax is spent on fixed investment in the country's corporate sector (in $2011-17.2 \%)^{7}$

In the context of this use of their own resources and additional financial resources that are received from the state in the form of tax incentives it is highly unlikely that the problem of the restructuring of the Russian economy can be solved.

To solve this problem, it is necessary to purposefully with the use of economic methods force companies to carry out modernization and renewal of production. In our opinion, this can be achieved only if all the tax benefits will be targeted and taxpayers can use them only if they follow the statutory conditions. It should be emphasized that the targeted tax reliefs are usually only available to specific sectors of the economy, and the state can actively adjust investment processes using tax methods.

In terms of this, the authors propose to abolish tax reliefs that are not targeted and to simultaneously introduce the complete tax exemption for the part of the profit that is actually used by a taxpayer for investment and innovation.

At the same time, it is important to take into account another point: the reduction of the rate of value added tax will be stimulating for the development of primarily manufacturing industries because this is where there is a higher level of added value in comparison with the extractive industries.

\subsection{The increasing role of depreciation policy}

The second direction of investment and innovation activity stimulation of Russian business should be an increase of the role of depreciation.

In economically developed countries depreciation charges over the past few decades have become a major system factor of stable development and modernization of the economy. In most of these countries depreciation charges account for about $70-75 \%$ of the total sources of financing investments in fixed assets. In the Russian economy this share is just over $20 \%$ (according to the report for the year $2011-21.6 \%)^{7}$

A fundamentally new and active depreciation policy contributed significantly to the powerful rise of the Chinese economy. It is important to stress another important fact. As for the use of depreciation the Russian economy actually lost the advantage, which it had in the last years of 
the former Soviet Union.

Such an active role of depreciation charges in the development of the economy in most countries is largely achieved through the mechanism of accelerated depreciation of fixed assets, the extensive use of which is objectively caused by the depreciation of fixed production assets that is both physical and moral.

Despite the fact that the Russian tax legislation predetermines the use of this mechanism (non-linear method of its calculation for the active part of fixed assets, the use of raising factors), its effectiveness and impact on the investment activity are clearly not sufficient. In the total amount of depreciation charges about 3\% account for the charges accrued through an accelerated method.

As the figures show in the Russian economy depreciation policy is passive, as a result the depreciation is barely fulfilling its main purpose - the increase of investment activity and renewal of fixed assets. Meanwhile, in the present, the main production factor is not the physical but the moral depreciation of fixed assets, which requires their quick update.

The proposed amortization reform, in our opinion, should provide for the implementation of the following priority actions that affect the sphere of taxation.

First of all, it is necessary to provide for the intended use of the assessed amount of depreciation for tax purposes by the taxpayers. To achieve this, when calculating the tax base of corporate income tax, it is required to include in it the depreciation amounts that are not accrued but are actually aimed at the renewal of fixed assets. At the same time, perhaps, it is necessary to introduce for a fixed term (5-7 years) the moratorium on the investment of depreciation amounts into financial assets. Only in these circumstances the depreciation charges can become a powerful incentive for the economic development through the renovation and modernization of fixed assets. It should be emphasized that the ban on the use of depreciation for other goals, which are not connected with direct investments in fixed assets, is implemented in many economically developed countries.

We proposed to introduce for a period of up to 10 years the compulsory progressive accelerated depreciation of the active part of fixed assets in the industries that define the scientific and technical progress. This will give an opportunity not only to obtain additional sources of modernization of the Russian economy but also to accelerate the development of technology by updating the active part of fixed capital by the withdrawal of the machinery and equipment from service before the expiration date of their service.

It will be almost impossible to carry out the modernization of the Russian economy if you do not take appropriate measures for the early decommissioning of the fixed assets with an extremely high degree of wear. In our opinion, this can be carried out once again through the depreciation mechanism. To achieve this, it is offered to apply the depreciation rate of $100 \%$ to the net book value to the fixed assets that have a degree of depreciation (wear) of more than $70 \%$.

Depreciation should certainly be a powerful incentive for the development of the Russian economy by transforming it from a way of recovery of used funds into the source for expanded reproduction.

\subsection{Modernization the mechanism of investment tax credit}

An important additional source of financing the implementation of investment and innovation 
projects in economically developed countries has become a tax credit. This mechanism was introduced in the Russian tax system almost from the first years of its formation and it was called the investment tax credit. It is designed to provide state financial assistance to businesses in the implementation of the investment and innovation, it has not yet been widely used.

Official statistics show that on the whole in the economy the amount of the investment tax credit provided for the business ranged between 300-500 million rubles in some years, which cannot have practical significance for the modernization and technical re-equipment of the production for such a huge country as Russia.

If we talk about the causes of the situation, they can be summarized in two words: granting conditions. Firstly, we should note the limitation of the scope of the investment tax credit: the implementation of the capital expenditure presupposes that it is granted solely for the technical re-equipment of production. The major reasons for the unpopularity of the loan also include the limited time of its return, the need for the harmonization of the amount of credit in the implementation or innovation activities, the limitation of the amount of credit by the upper limit of current tax payments, narrowing the list of tax for which credit can be given.

In our opinion, for the development of this important taxation tool it is necessary to make the following changes to the procedure and conditions of the investment tax credit. The area of its application should be significantly expanded, taking into account the fact that it can be provided for the implementation of any investment, innovation and research projects in the sphere of material production. In order to increase the effectiveness of the guarantee corresponding to the project some changes in the existing conditions of its provision should be proposed. In particular, the borrower's involvement in financing of the project should be restricted to $10-15 \%$. For the government the extra payback guarantee of the project could be provided by a partial involvement of its bank financing resources. At the same time, the federal government can provide the investment tax credit only for corporate income tax.

However, the overwhelming proportion (85\%) of the tax goes to the budgets of the subordinate territories of the Russian Federation, which virtually eliminates the possibility of federal agencies to provide this particular loan. In our opinion, the list of taxes to the federal budget, which give the opportunity to provide the loan, should be expanded. This concerns primarily the value-added tax, the tax on extraction of minerals. Probably the import duties should be the source of the investment tax credit.

A detailed discussion of the problem also requires the current legislation to limit the size of the amount of tax that may be aimed at obtaining the tax credit. As an important point for the restriction of the investor's decisions to apply for a loan we should consider a reduction of the limit of current payments under the relevant tax at a rate of $50 \%$.

In our opinion, the payments on the loan should be made by the taxpayer within the entire tax amount by which it was obtained. It is also necessary to revise the target date of the investment tax credit, which is now not more than five years.

The expansion of the practice of the investment tax credit is very important in the present period, especially for producers that are transitioning to resource-saving technologies, introducing technical innovation, developing production facilities in depressed regions that are currently involved in import substitution.

The proposed tax arrangements would, in our opinion, create appropriate conditions and 
incentives for the Russian business to upgrade machinery and equipment, which will ensure the implementation and development of modern technologies in the Russian economy, the implementation of innovative projects and the modernization of the country's economic system.

\subsection{Reducing the tax burden on business}

Currently the key issue for the modernization of the Russian economy is the problem of the admission decision of raising the tax burden on the economy, and especially - on business. As it is known, the quantitative measure of this index is currently the ratio of the amount of taxes paid to the gross national product. However, this figure, in our opinion, is not efficient enough, since it only reflects what the measures - that is, the level of GDP redistribution through the tax system. As a result, it is impossible to determine what the actual level of the tax burden on the population, on business, on the good faith of the taxpayer is. That is why, it is not surprising that the value of this indicator is differs from country to country. In particular, the ratio of taxes paid to the GDP in Sweden is 44.3\%, Denmark - 47.7\%, in Finland - 43.4\%, in the UK - 36.1\%, and in Bulgaria, Latvia and Romania - $26-28 \%{ }^{8}$

In Russia, this figure has not risen above $35-36 \%$ in recent years. The fact is that this index value in each country is greatly influenced by a set of many specific factors.

The problem of income tax in Russia exists because of the uneven distribution of the tax burden among the various segments of the population. While in other countries income tax rates are set in such a way that the labor income taxes are substantially lower than the net income taxes, the main income in Russia is provided by payroll taxation. In particular, in the US even in the presence of relatively low rates of personal income tax, if we compare them to most Western European countries, more than $70 \%$ of all tax revenue comes from net income taxation with the most affluent taxpayers with annual income from it of over $\$ 100000$ that account for only $10 \%$ of the total sum. ${ }^{9}$

In the Russian tax system income tax for individuals - this is a tax on the poor. This is directly connected with the existence of a single rate of taxation of almost any income in the absence of taxation on gross annual income, as well as the exemption from taxation of certain types of capital income. Meanwhile, income from capital is the main source of high and ultrahigh income of individuals around the world, including Russia. According to Rosstat, in the whole country the share of incomes from work payments amounted only to $41.6 \%$ in 2014 . However, other income, including income from property and hidden wages amounted to $32.0 \% .{ }^{10}$ According to Rosstat report for 2015 the total income of Russia's population totaled 53.1 trillion rubles, and the property income only accounted for 3.5 trillion rubles. ${ }^{11}$

Simultaneously it is necessary to introduce a progressive scale of taxation of the gross annual income. In our opinion this will provide a significant increase in revenues and will not reduce the level of labor activity, since the progression of taxation will be distributed mainly on income not from work payments but from capital (securities, deposits, disposal of assets, royalties and so on), which is much more difficult to hide than income from salary. For the purpose of redistribution of the tax burden among the population it is also necessary to restore the previously existing in the Russian tax system the inheritance tax and gift tax with progressive tax rates and non-taxable amount of the inheritance. 


\section{Conclusions}

Both the world experience and the analysis of the Russian practice show that the effective tax mechanisms are an important factor for the economic development. The authors believe that the directions of development and improvement of tax mechanisms proposed in this paper will not only increase the investment activity, accelerate the process of renewal of fixed assets and increase the pace of economic development growth but will also make the Russian tax system more equitable and efficient.

\section{References}

1. URL: http://www.gks.ru.

2. URL:http://www.gks.ru/wps/wcm/connect/rosstat_main/rosstat/ru/statistics/enterprise/ fund/

3. V.G. Panskov, About certain theoretical aspects of the notion 'tax relief', Finance and credit, 4 (2014) 43 - 49

4. URL: http://www.gks.ru. The following numbers are taken by the authors from the statistics and analytical materials of the Federal Service of State Statistics in the chapters: 'Main funds', 'Organization finance', 'Entrepreneurship'.

5. URL:http://www.gks.ru/wps/wcm/connect/rosstat_main/rosstat/ru/statistics/enterprise/ investment/nonfinancial/\# $(09.11 .2016)$

6. URL:http://www.gks.ru/wps/wcm/connect/rosstat_main/rosstat/ru/statistics/enterprise/ investment/investing/\# (09.11.2016)

7. Rosstat Bulletin №1. Main figures of investment and construction activity in Russia. M. 2012. p. 15.

8. Taxation trends in the European. Eurostat. 2015.

9. Statistical Abstract of the United States. 2009. Table 470.

10. URL: http://www.gks.ru/free_doc/new_site/population/bednost/tabl/1-1-2.doc (08.04. 2016).

11. URL:http://www.gks.ru/wps/wcm/connect/rosstat_main/rosstat/ru/statistics/population level/\# (01.10. 2016) 